\title{
Knowledge of HIV AIDS and Sexual Risk Transgender Women Behavior on Suburban City of Indonesia
}

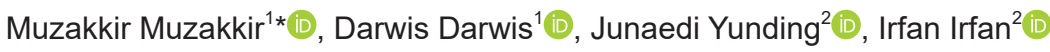 \\ ${ }^{1}$ Department of Nursing, STIKES Nani Hasanuddin, Makassar, Indonesia; ${ }^{2}$ Department of Nursing, Faculty of Health, Universitas \\ Sulawesi Barat, Majene, West Sulawesi, Indonesia
}

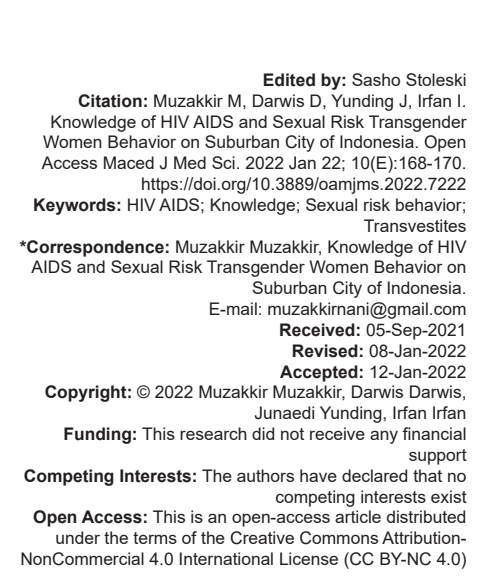

Abstract

BACKGROUND: Transvestites are male sex-oriented women and look like women, transvestites physically want to look like women and psychologically identify themselves as women.

AIM: This study aimed to determine the relationship between knowledge about HIV AIDS and risky sexual behavior in transvestites.

METHODS: The research design used was Analytical Observational with a Crossectional Study approach. The number of samples of 103 people was selected by Purposive Sampling from all transvestites in Majene Regency. Retrieving data using knowledge questionnaires and risky sexual behavior. Data were analyzed using Fisher's Exact Test.

RESULTS: Average age of 25.33 years (SD = 4.43). Only about $13 \%$ had received university or higher education. The results of this study indicate that $33.0 \%$ with high-level knowledge categories and $67.0 \%$ categories of lowerlevel knowledgeable results showed a value of $\mathrm{p}: 0.007$.

CONCLUSION: There is a relationship between knowledge about HIV AIDS and risky sexual behavior in transvestites with p: 0.007 .

\section{Introduction}

In Indonesia, transsexuals or transvestites (Men) have not received recognition from the public because Indonesian state law only recognizes two sexes, namely, men and women [1]. Sex refers to the physical state of human reproduction. This causes transvestites not to get a place socially in the community so that transvestites are considered "deviant" by the community. From a psychological perspective, a transsexual is a form of sexual deviation both in the desire to get sexual satisfaction and the ability to achieve sexual satisfaction [2].

The sexual lifestyle of transvestites is reflected in sexual activities, such as changing partners, not using condoms, and having anal and oral sex [3]. This causes the lives of transgender women to be very vulnerable and at risk of psychological and sexual violence, thus impacting the possibility of transmission and spread of sexually transmitted infections (STIs) and human Immuno Deficiency Virus and Acquired Immune Deficiency Syndrome (HIV AIDS). Over the past decade, the prevalence of STIs, especially HIV infection, in the transgender community has reportedly increased significantly [2]. In 2011 the World Health Organization announced 34 million people had HIV that causes AIDS, and most of them lived in poverty and developing countries [4].

Based on data from the Department of Disease Prevention and Control, Indonesian Ministry of Health in 2016, HIV AIDS cases in 2015 were 6,081 cases from the five highest provinces, namely Central Java 963 Cases, Bali 957 Cases, West Java 657 Cases, East Java 647 Cases, and East Kalimantan 254 cases, while HIV AIDS cases in 2016 increased by 7,491 cases from the five highest provinces, namely Central Java 1,402 cases, East Java 1,110 cases, Bali 882 cases, South Sulawesi 571 cases, DKI Jakarta 555 cases.

Judging from the prevalence of HIV AIDS in 2016, South Sulawesi was ranked $4^{\text {th }}$ [5]. In Jakarta, the results of a mid-2015 seroprevalence survey of 241 transgender CSWs showed that HIV prevalence and early syphilis reached $22 \%$ and $19.3 \%$. This is a significant improvement compared to the previous surveys [2]. Data for West Sulawesi Based on data from the Directorate General of P2P, Indonesian Ministry of Health in 2016, HIV AIDS cases in 2015 were 13 cases. In 2016, it increased to 22 HIV AIDS cases (Indonesian Ministry of Health 2016). From the Majene district service survey results in 2016, the number of HIV AIDS sufferers was five people, HIV as many as three people, and AIDS 2 people [6]. 
Research conducted by UNAIDS in 2013 concluded that male sex with men was the spread factor of the fastest HIV epidemic in the world. Global studies have found that transgender women are 50 times more likely to contract HIV than productive age couples. This concludes that transgender and transgender people are very vulnerable to HIV [7]. The deviation of sexual behavior in transgender people is to have a sexual lifestyle inherent in her that is influenced by the social and cultural environment and impacts her health. Preventive efforts play an important role in reducing the number of new HIVIAIDS infections [8]. Preventative measures can be through behavior change and reducing stigma and discrimination against people with HIVIAIDS. In realizing this, it is necessary to increase the knowledge and awareness of the consequences or consequences of risky behavior [9]. Knowledge can improve one's understanding and influence decision-making [10]. Studies related to HIVIAIDS in populations at risk, such as commercial sex workers, male customers of WPS (Female Sex Workers), have been researched by many previous researchers.

In contrast, research for men who like men (MSM, gay and transgender) has not been conducted, especially in Majene Regency. Based on the interviews with several transvestites they said that there were around 40 transvestites in Majene District and noted that transgender people prefer to discuss sexual behavior. This raises the author's interest to find out how the relationship of knowledge about HIV AIDS with risky sexual behavior in transvestites.

\section{Methods}

This study uses quantitative research methods. The design of the study uses observational analytic with a crossectional Study approach. This research was carried out in Majene and surrounding districts in 2017 with some 103. Samples are taken by Purposive Sampling, which is based on the fulfilment of Criteria: Able to communicate well, someone who physically and mentally leads to women. The research questionnaire used is a questionnaire of characteristics (age and education), knowledge, and behavior of respondents. Data analysis was univariate and bivariate analysis using the Chisquare test, and the significance level was $p<0.05$.

\section{Results}

As shown in Table 1 , the average age of 25.33 years $(S D=4.43)$. Only about $13 \%$ had received university or higher education. The results of this study
Table 1: Characteristics of respondents

\begin{tabular}{ll}
\hline Variable & Total $(\mathrm{n}=103)$ \\
\hline Mean Age (M \pm SD) & $(25.33 \pm 4.43)$ \\
Education & \\
Junior high or lower & $67 \%$ \\
Senior high & $23 \%$ \\
$\quad$ College or higher & $13 \%$ \\
Level Knowledge & \\
$\quad$ High & $33.0 \%$ \\
$\quad$ Lower & $67.0 \%$ \\
Behavior & \\
$\quad$ Risk & $72.8 \%$ \\
No Risk & $27.2 \%$ \\
\hline
\end{tabular}

indicate that $33.0 \%$ with high-level knowledge categories and $67.0 \%$ categories of lower-level knowledge. This proves that most of the respondents do not know the understanding, causes, modes of transmission, symptoms, and ways to prevent HIVIAIDS.

Analysis of the relationship between knowledge of HIV AIDS and risky sexual behaviors in transvestites showed that $14.6 \%$ of the respondents who had highlevel knowledge of non-risk sexual behavior, $18.4 \%$ had high-level knowledge of risky sexual behavior, and $75.0 \%$ respondents with lower-level knowledge and behavior are at risk for HIV AIDS. The analysis of the relationship between the two variables above using the SPSS statistical test shows the significance of the relationship between the two variables using the Chisquare test $(p=0.007)$, the results of this study have a significant relationship between knowledge about HIV AIDS with risky sexual behavior in transgender (Table 2).

Table 2: Relationship between knowledge and behavior $(n=103)$

\begin{tabular}{llll}
\hline Variable & \multicolumn{2}{l}{ Behavior } & Chi-square \\
\cline { 2 - 3 } & Risk & No-Risk & \\
\hline Level Knowledge & $18.4 \%$ & $14.6 \%$ & 0.007 \\
High & $75.0 \%$ & $12.6 \%$ & \\
$\quad$ Lower & & & \\
\hline
\end{tabular}

\section{Discussion}

The results of this study prove that the level of education is not following the existing theory, which states that the higher the level of education of a person, the easier it is for someone to receive information. With higher education, someone will get information from other people and the mass media. One factor that plays a role in knowledge is education, whether formal or non-formal education. Knowledge is much influenced by formal education, so knowledge is closely related to education.

The results of this study indicate that respondents with non-risk behavior as many as $27.2 \%$ and respondents with risk behaviors for HIV AIDS as many as $72.8 \%$. This proves that almost all respondents have had sexual relations following this "Deviance of sexual behavior in transgender people is to have a sexual lifestyle inherent in him which is influenced by the social and cultural environment around him and impacts his health. Sociological factors cause the factor of behavior 
change in transgender. These environmental influences impact changes in sexual behavior in transgender women with HIV AIDS risk" [2]. According to the theory of Lawrance Green that behavior is formed by several factors [11]: 1). Predisposing factors that are manifested in knowledge, attitude, and accountability 2). Supporting factors manifest in the physical environment, the availability of facilities or infrastructure, 3 ) reinforcement factors displayed in attitudes and behavior.

The problem that arises in this study is that there were $25.0 \%$ who were well-informed but had risky sexual behavior. This study is the same as the results of a survey from Kumalasari (2014), which showed that there were $24(42.1 \%)$ students who were knowledgeable about engaging in premarital sexual behavior [12]. This is very contrary to the existing theory. The higher the knowledge, the lower the premarital sexual behavior; on the contrary, the lower the knowledge, the higher the premarital sexual behavior [13]. Several factors, including environmental factors, can influence this. Based on the research results of Rahmayani et al. (2014), there was a significant relationship between the level of knowledge and the prevention of HIVAIDS transmission in transgender in the city of Padang [14]. This proves that the respondents already understand enough to prevent HIV-AIDS. A good level of knowledge is felt to play an important role in the prevention of HIVAIDS [15]. Knowledge of HIV status is relatively high in eastern Europe and Central Asia, but treatment coverage and viral suppression are alarmingly low [16].

Transgender is one of the high-risk groups that spread HIVIAIDS; its existence is quite worrying because of the activities inherent in their daily lives [17]. Sexual activity in transgender sex workers is considered high risk because they have many male sexual partners. Most likely, their partners also have many other male sexual partners, both married/unmarried men [14].

\section{Conclusion}

The conclusion of the study is that respondents with a low understanding of HIV AIDS are quite high, namely, $67 \%$ and the high number of respondents who have bad behavior is at risk of getting HIV AIDS as much as $72.8 \%$. Then, there is a significant relationship between knowledge about HIV AIDS with risky sexual behavior in transgender $(p=0.007)$.

\section{References}

1. Afif MB. Islam and transgender (A study of hadith about transgender). Int J Nusantara Islam. 2019;7(2):2. https://doi.org/10.15575/ijni.v7i2.6138

2. Rokhmah D. Pola asuh dan pembentukan perilaku seksual berisiko terhadap HIVIAIDS pada waria. KEMAS. 2015;11(1):3617. https://doi.org/10.15294/kemas.v11i1.3617

3. Rudi A, Haryanti Y, Masan L, Maretalinia, Yulianto A. The determinants of sexually transmitted infections (STIs) among female sex workers (FSWs) in Indonesia: A literature review. J Health Epidemiol Commun Dis. 2020;6(1):15-24.

4. World Health Organization. WHO, UNICEF, and UNAIDS, Global HIVIAids Response, Epidemic Update and Health Sector Progress towards Universal Access. Geneva: World Health Organization; 2011.

5. Kemenkes RI. Communicable Diseases and Environmental Health (StatistikKasus HIV-AIDS). Jakarta: Ditjen PP and PL Kemenkes RI; 2016.

6. Dinas Kesehatan Kabupaten Majene, Gambaran Kasus HIV dan AIDS di Kabupaten Majene Tahun 2016. Majene: Dinas Kesehatan Kabupaten Majene; 2016.

7. APTN and UNDP. Lost in Transition: Transgender and HIV Vulnerability in the Asia-Pacific Region. New York: United Nations Development Programme; 2012.

8. Bertozzi S, Padian NS, Wegbreit J. HIVIAIDS prevention and treatment. In: Jamison DT, Breman JG, Measham AR, Alleyne G, Claeson M, Evans DB, Jha P, Mills A, Musgrove P, editors. Disease Control Priorities in Developing Countries. $2^{\text {nd }}$ ed. Washington, DC: World Bank; 2006.

9. Coates TJ, Richter L, Caceres C. Behavioural strategies to reduce HIV transmission: How to make them work better. Lancet. 2008;372(9639):669-84. https://doi.org/10.1016/ S0140-6736(08)60886-7

PMid:18687459

10. Suominen $\mathrm{T}$, Koponen $\mathrm{N}$, Mockiene $\mathrm{V}$, Raid $\mathrm{U}$, Istomina $\mathrm{N}$, Vänskä ML, et al. Nurses' knowledge and attitudes to HIV/ AIDS--an international comparison between Finland, Estonia and Lithuania. Int J Nurs Pract. 2010;16(2):138-47. https://doi. org/10.1111/j.1440-172X.2010.01822.x

PMid:20487059

11. Davis R, Campbell R, Hildon Z, Hobbs L, Michie S. Theories of behaviour and behaviour change across the social and behavioural sciences: A scoping review. Health Psychol Rev. 2015;9(3):323-44. https://doi.org/10.1080/17 437199.2014.941722 PMid:25104107

12. Kumalasari D. Correlation of knowledge and attitude with premarital sexual behavior toward the student in SMK. J Aisyah. 20161(1):1. https://doi.org/10.30604/jika.v1i1.13

13. Rahmatin R, Laksono B, Rustiana ER. Adolescent sexual behaviour at risk of unintended pregnancy and HIVIAIDS. Public Health Perspect J. 2018;3(2):2.

14. Rahmayani V, Hanif AM, Sastri S. Hubungan pengetahuan dan sikap dengan tindakan pencegahan penularan HIV-AIDS pada Waria di Kota Padang Tahun 2013. J Kesehatan Andalas. 2014;3(2):2. https://doi.org/10.25077/jka.v3i2.99

15. Youssef L, Hallit $S$, Sacre $H$, Salameh $P$, Cherfan $M$, Akel $\mathrm{M}$, et al. Knowledge, attitudes and practices towards people living with HIV/AIDS in Lebanon. PLoS One. 2021;16(3):e0249025. https://doi.org/10.1371/journal. pone. 0249025

16. UNAIDS. Knowledge is Power: Know your Status, Know your Viral Load. New York: United Nations; 2019.

17. Feldman J, Romine RS, Bockting WO. HIV risk behaviors in the US transgender population: Prevalence and predictors in a large internet sample. J Homosex. 2014;61(11):1558-88. https:// doi.org/10.1080/00918369.2014.944048

PMid:25022491 